\author{
Ivo Šlosarč̌ k
}

DOI: $10.33067 /$ SE.1.2019.06

\title{
Constitutional Design, Rule of Law and Mutual Recognition in the Czech Republic ${ }^{\star \star}$
}

\begin{abstract}
The article analyses the potential EU dimension of the impunity of the President of the Czech Republic and the President's constitutional competencies concerning criminal law. Based on recent development of constitutional practice in the Czech Republic and new trends in EU law, the article formulates potential conflict scenarios between Czech constitutional rules and the EU principles of non bis in idem and the rule of law.
\end{abstract}

Key words: European Union, President of the Czech Republic, Constitution, Mutual recognition, criminal law, EU law, non bis in idem

\section{Introduction}

This article analyses two aspects of the constitutional position of the President of the Czech Republic ("the President"): the presidential power of clemency in criminal matters and the constitutional framework of presidential impunity. The article identifies a connection between the abovementioned constitutional issues and the membership of the Czech Republic in the European Union as well as demonstrating their potential to trigger a conflict with core rules of the functioning of the EU, such as the principle of mutual recognition and the rule of law.

^ Ivo Šlosarčík - Charles University, Prague, e-mail: slosarcik@fsv.cuni.cz, ORCID: 0000-0002-2764-4290.

$\star \star$ This study was supported by the Charles University Research Programme "Progres" Q18 - Social Sciences: From Multidisciplinarity to Interdisciplinarity a Jean Monnet Centre of Excellence NIECE. 


\section{The Position of the President in the Constitutional System of the Czech Republic}

The President of the Republic is one of centres of the dual executive branch of the Czech Republic; the second one being represented by the government chaired by the Prime Minister. The Constitution of the Czech Republic vests the President with a heterogeneous catalogue of competencies. Firstly, the constitution provides the head of state with autonomous powers performed by the President without intervention of other constitutional actors, such as a competence to veto ordinary legislation, to refer laws to the Constitutional Court or to appoint members of the Banking Council of the Czech National Bank. Secondly, some presidential powers require approval of other (nonexecutive) actors. The most important example of this second category is the presidential appointment of judges of the Constitutional Court which must be approved by the Senate (upper chamber of the Parliament of the Czech Republic). Thirdly, the constitution also vests the President with powers that must be performed only by mutual agreement between the President and the government (Prime Minister). The most important items on the list of shared constitutional presidential competencies are appointment of judges of general courts, appointment of ambassadors and generals, negotiation and ratification of international treaties as well as external representation of the Czech Republic in general. Fourthly, the powers of the President of the Republic have been frequently extended by ordinary, non-constitutional, legislation. This option has been used, for example, to empower the President to appoint university professors and university rectors or to select the chairperson of the Supreme Administrative Court. These legislative-based presidential powers are performed in coordination with the government, i.e. the respective decision must be signed both by the President and the Prime Minister. Finally, the catalogue of presidential competencies is supplemented by activities not directly derived from the constitution or legislation, such as media performances and publication activities (not approved by the government) with potential implications for domestic and foreign policy.

In practice, every President of the Czech Republic (Václav Havel, Václav Klaus, Miloš Zeman) has attempted to interpret the constitutional rules regulating his position extensively, using either direct confrontation with the government or by referring to the Constitutional Court. This tension between the formal constitutional rules and the constructional practice has only strengthened since the establishment of direct presiden- 
tial elections by a constitutional amendment in $2012 .^{2}$ The reason behind this is the fact that while the legitimacy of the President has increased due to the new election format (direct elections at present versus former elections by the Parliament), the catalogue of presidential powers has been altered almost exclusively on a technical level. ${ }^{3}$ Hence, the current President Miloš Zeman seems to tackle this gap between new legitimacy and old competencies with an almost permanent struggle to alter the constitutional practice, in particular when potential political opponents (such as the Prime Minister and/or leaders of key political parties) have been weakened by their individual problems or by structural changes of the political environment. Consequently, the predictability of the behaviour of the President has decreased during the incumbent presidency, including its dimension related to European Union affairs. The following two sections of this article shall deal with two aspects of the President's behaviour and its potential European implications: firstly, wrongful acts of the President and their consequences and, secondly, the presidential right of clemency in criminal matters.

\section{Wrongful Acts Performed by the Head of State}

The President of the Czech Republic benefits from strong constitutional protection. The constitutional Article 54 states that the President "shall not be responsible for the performance of his duties." While the main purpose of the constitutional clause is to shield the President from general prosecution for criminal offences or misdemeanours, ${ }^{4}$ the presidency of Miloš Zeman has generated controversies which have tested the limits of presidential impunity concerning other types of activities of the President.

In January 2015, Miloš Zeman delivered a speech at a conference commemorating the liberation of the Auschwitz concentration camp. The President stated that a famous Czech journalist Ferdinand Peroutka wrote an article named "Hitler Is A Gentleman." The statement was rather surprising, since Ferdinand Peroutka has been known for his fierce opposi-

2 Ústavní zákon č. 71/2012 Sb., kterým se mění ústavní zákon č. 1/1993 Sb., Ústava České republiky (Constitutional act no. 71/2012 Coll., amending constitutional act no. 1/1993 Coll.).

3 M. Antoš, Pravomoci prezidenta republiky po zavedení prímé volby (Competencies of the President of the Republic after Direct Presidential Elections), "Acta Universitatis Carolinae Iurudica“, no. 4/2011, pp. 27-42.

4 However, the constitution permits an impeachment of the President for "high treason, gross violation of the Constitution or other segments of the constitutional order“. 
tion to the Nazi regime, spending the majority of WWII in Buchenwald concentration camp. Zeman's comment on Peroutka, used by the President to demonstrate a moral failure of a public intellectual, was almost immediately questioned by Czech historians as well as Peroutka's family. ${ }^{5}$ Moreover, the article referred to by the President could not be found in any library archive or academic publication.

Despite all critiques and lack of material evidence, the President refused to correct his statement or to apologise. Consequently, Peroutka's granddaughter challenged the President's behaviour before the Czech courts in April 2015. Due to several appeals, the judicial procedure had not reached a final decision by September $2018 .{ }^{6}$ However, even the pending procedure provides both an insight into the interpretation of Czech rules on freedom of speech and defamation as well as opening several constitutional questions.

The first constitutional issue is whether the President's speech benefits from the impunity guaranteed by the constitution. The respective constitutional clause mentions impunity in situations when the President "performs his duties." The alleged defamatory statements challenged in the judicial dispute were not contained in an official act of the President but "only" in a speech delivered at a high-profile international conference. Therefore, it could be argued that the speech was private conduct of the President not benefiting from privileged constitutional protection. Neither the constitution nor the constitutional practice provides for a clear delimitation between the private and official activities of the President, as demonstrated by Václav Havel's signature of the "Letter of Eight" in 2003. ${ }^{7}$ In a different case, the constitutional court of former Czechoslovakia ruled that the definition of official duties of the President covered by the impunity clause is not exhausted by those presidential

5 Peroutka died in exile in 1978.

6 The case was decided by the first instance court in Prague (deciding in favour of the applicant against the President), then by the appelate court (partially upholding the decision of the court of the first instance) and then by the Supreme Court which annuled the decision of the lower courts, thus opening a procedural path for re-trial according to the interpretational instructions formulated in the verdict of the Supreme Court.

7 The "Letter of Eight", supporting the idea of the US-led military operation in Iraq in 2003 was signed by prime ministers from Denmark, Hungary, Italy, Poland, Portugal, Spain and the UK, as well as by the President of the Czech Republic. The government of the Czech Republic did not formally approve Havel's signature which was made literally only a few days before the end of Havel's presidential term. Vaclav Havel argued that he signed the letter in his private capacity, i.e. outside the performance of his presidential duties and thus not requiring the approval of the government. 
acts enumerated in the constitution or legislation. Further, Czechoslovak constitutional judges agreed that in borderline cases presidential activity shall be considered as activity benefiting from the constitutional impunity regime. In the Peroutka case, the plaintiff, the defendant and the intervening courts agreed on the idea that the presidential speech, albeit prepared without intervention and/or approval of the government, fell within the sphere of activities covered by the presidential impunity clause of the constitution. ${ }^{8}$

The second constitutional question is to identify an institution which could act as a defendant in a situation when wrongful behaviour of the President is covered by the constitutional impunity clause. The most likely candidates for the role of a "surrogate defendant" in the Peroutka case are the Office of the President or the Ministry of Justice, both representing the Czech Republic. The identification of the proper defendant is directly dependent on the specific legal act used as the basis for the judicial procedure. Since the constitution is silent concerning this question, ${ }^{9}$ two legislative acts are the most likely vehicles for the procedure: general legislation on defamation and protection of personal integrity regulated primarily in the Czech Civil Code,$^{10}$ and specific legislation on liability of the Czech Republic for illegal decisions and irregular behaviour of the administrative bodies. ${ }^{11}$ In the first phase of the procedure, the defamation procedural avenue was used by the plaintiff, ${ }^{12}$ while the Supreme Court seems to prefer the specific legislation on state liability to be used.

There is an obvious third possible interpretation of the impunity clause in the constitution that claims that no institution is liable for presidential activities such as those performed in the Peroutka case. At present, it seems that the existence of a sphere of wrongful presidential activities with no institution liable for them has been rejected by all the par-

8 I. Šlosarčík, Constitutional Development in the Czech Republic in 2013-2017: Direct Presidential Elections and Their Constitutional Consequences, "European Public Law", no. $1 / 2018$, pp. 43-53.

9 The constitutional text only states (in constitutional Article 63 paragraph 4) that the government is liable for the President's decisions co-signed by the Prime Minister.

10 Zákon č. 89/12 Sb. Občanský zákoník (act no. 89/12 Coll. Civil Code).

11 Zákon č. 82/98 Sb. Zákon o odpovědnosti za škodu způsobenou při výkonu veřejné moci rozhodnutím nebo nesprávným úředním postupem (act no. 82/98 Coll. on liability of the state for damage caused by exercise of public authority by decision or by irregular administrative conduct).

12 The plaitiff's position was supported both by the first instance and the appelate courts which ordered the Office of the Government to apologise (on behalf of the Czech Republic) for the defamatory statements in the President's speech. 
ties involved in the dispute as well as by the Czech courts. In the courts' opinion, an absolute absence of liability for wrongful acts performed by the president would, by creating an endemic pocket of irresponsibility in the legal system, be incompatible with the principle of the rule of law, as contained in the first article of the Czech constitution.

The above-mentioned argument also creates a connection between the constitutional design of the Czech Republic and its membership in the European Union. Rule of law is not only a constitutional principle of the Czech state but also a principle protected by European Union law. Therefore, a scenario is possible when the emergence of a constitutionally based "pocket on non-liability" for wrongful acts of a state authority (e.g. the President) would be considered as incompatible with key principles of European integration, as enumerated in article 2 TEU. An analogous conflict may also emerge, when the rules defining the scope and format of state liability for wrongful acts of the President would be so obscure and unpredictable (due to unclear legislation or due to procedural and jurisprudential obstacles) that their enforceability would be very difficult or even only theoretical. As mentioned above, the emergence of such a conflict is relatively unlikely but, in light of the fact that the judicial review of the Peroutka case is far from being completed in 2018, not purely theoretical.

\section{Presidential Power of Pardon in Criminal Matters}

The Czech constitution vests the President with a capacity to intervene in a criminal procedure. The president has full autonomy to pardon (fully or partially) any individual sentenced in a criminal procedure in the Czech Republic. ${ }^{13}$ Further, with the approval by the Prime Minister, the President is authorised to issue non-individualised amnesties as well as to terminate a criminal procedure against an individual before delivery of the final verdict by the court. ${ }^{14}$

In particular during the presidencies of Václav Havel and Václav Klaus, use of individual pardons and general amnesties was relatively widespread. Miloš Zeman has used his prerogatives in the criminal sphere less frequently. Some individual pardons and amnesties triggered both academic debate and political critique, such as the 2017 decision of Miloš

13 Article 62: The President (g) "may grant pardons or commute sentences imposed by courts and order that a criminal record be expunged".

14 Article 63: The President (j) "orders that the criminal proceedings not be instituted or if it has been instituted, that it be discontinued"; (k) "has the right to issue amnesties". 
Zeman to pardon Jiří Kajínek, sentenced to life imprisonment for a double murder, or an amnesty decided upon by Václav Klaus in 2013 which terminated the criminal prosecution of many (alleged) white collar crimes linked with the economic transformation and privatisation in the Czech Republic. However, there is another potentially controversial element of the presidential clemency power in criminal matters, this time connected with the membership of the Czech Republic in the European Union, and with the "Europeanised" principle no bis in idem in particular.

EU law has expanded the non bis in idem principle, usually guaranteed by the national constitutions of member states, onto the EU level. EU law enshrines the principle in the Charter of Fundamental Rights of the European Union whose article 50 states that "no one shall be liable to be tried or punished again in criminal proceedings for an offence for which he or she has already been finally acquitted or convinced within the Union in accordance with the law." Even before the Charter was turned into a binding EU law, the non bis in idem rule was inserted into the Schengen Implementing Convention whose article 54 declared that "a person whose trial has been finally disposed of in one Contracting Party may not be prosecuted in another Contracting Party for the same acts provided that, if a penalty has been imposed, it has been enforced, is actually in the process of being enforced or can no longer be enforced under the laws of the sentencing Contracting Party". ${ }^{15}$ Further, the non bis in idem principle has been integrated into the European Arrest Warrant mechanism.

Differences between national procedural laws in criminal matters and the ambiguity of the EU legal texts required both national courts and the Court of Justice of the European Union to tackle several interpretation issues in their case-law. For the purpose of an analysis of the interaction between the non bis in idem principle and the constitutional powers of the President, the most important element is the judicial interpretation of the terms "finally acquitted or convicted" (in the Charter) and "trial has been finally disposed" (in the Schengen Implementing Convention) which activate the non bis in idem principle preventing prosecution in another state. It is important to stress that the EU legal texts do not explicitly require that the institution which issues the "final" decision must be a national court. Consequently, the Court of Justice of the European Union ruled that the non bis in idem principle can also be activated by an extra-judicial settlement approved later by a court (C-187/01 a C-385/01

15 The convention implementing the Schengen Agreement of 14 June 1985 between the Governments of the States of the Benelux Economic Union, the Federal Republic of Germany and the French Republic on the gradual abolition of checks at their common borders. 
Gözütuk and Brugge), acquittal due to lack of evidence (C-150/05 Van Straaten) or termination of a prosecution due to lapse of time (C-467/04 Gasparini). ${ }^{16}$

Therefore, even a presidential decision to terminate a criminal procedure before the final verdict of the Czech court could qualify as a decision capable of activating the non bis in idem principle in the whole EU. Consequently, the Czech constitution in combination with EU law could enable the President to "export" his constitutional prerogative outside the borders of the Czech state. However, two scenarios are conceivable when the requirement of the Czech Republic for "negative mutual recognition" of its presidential clemency decisions are challenged by other EU states. ${ }^{17}$ The first one is rejection of the interpretation that the given clemency decision constitutes a decision activating the Europenised non bis in idem principle. In particular, a foreign court could argue by the discretional character of the presidential clemency decision whose objective is not primarily to establish the criminal liability of a person prosecuted but to reflect upon other circumstances not always caught by a legal act. ${ }^{18}$ The second challenge can emerge in situations when the presidential pardon concerns crimes whose prosecution is required by the EU law. Then, an alleged violation of the principle of loyal cooperation by the Czech President ${ }^{19}$ could be claimed as a basis for rejecting acceptance of the bis in idem principle outside Czech borders in a particular case.

Neither form of conflict has emerged yet, primarily due to the small number of cases when the President Miloš Zeman uses his power of clemency. However, in the context of the rapidly expanding EU acquis in the domain of criminal law as well as due to new case-law permitting courts to divert from the mutual recognition which emerged in recent years (C-216/18 PPU Minister for Justice and Equality versus LM, C-404/15 Pál Aranyosi a Robert Căldăraru v. Generalstaatsanwaltschaft Bremen), the above-mentioned conflict between the Czech presidential prerogatives and the EU non bis in idem rule could materialise in the future.

16 A. Klip, European Criminal Law. An Integrative Approach, 3rd ed., Cambridge 2016, pp. 287-291.

17 I. Šlosarčík, Europeizace ústavniho postavení prezidenta České republiky (Europeanisation of the Constitutional Role of the President of the Czech Republic), "Jurisprudence", no. 2/2016, pp. 18-29.

18 Ústava České republiky. Komentár (Constitution of the Czech Republic. Commentary), eds. L. Balýlová, J. Filip, P. Molek, Praha 2010, pp. 727-731.

19 M. Klamert, The Principle of Loyalty in EU law, Oxford 2014, pp. 239-240. 


\section{Conclusion: Constitutional Design and Conflicting Principles of EU Law}

Analysis of the constitutional position of the President of the Czech Republic demonstrates that even those elements of constitutional design whose connection with European law seem to be vague and marginal, have the potential to trigger a conflict with core elements of the EU integration process. The two rules concerningthe President studied in this article, the liability for wrongful acts of the President and the presidential power of clemency, appear to be distant from the core European dimension of presidential activities, such as participation in the European Councils or his veto power over Czech legislation implementing European directives. However, scenarios when those two relatively marginal (from the EU perspective) examples of presidential activity could collide with the EU mechanism of mutual recognition and the rule of law principle could be constructed relatively easily, in particular taking into consideration the weakened predictability of Czech constitutional practice during the presidency of Miloš Zeman and new trends in EU law. This article does not formulate a simple solution to prevent or solve the above-mentioned conflict scenarios. Instead, it demonstrates ever-expanding potential for conflict between competing EU principles of respect for national constitutional identity (article 4 par. 2 TEU) and that of sincere cooperation in the EU (article 4 par. 3 ) in the post-Lisbon European Union.

\section{References}

Antoš M., Pravomoci prezidenta republiky po zavedení přimé volby (Competencies of the President of the Republic after Direct Presidential Elections), "Acta Universitatis Carolinae Iurudica," no. 4/2011, pp. 27-42.

Klamert M., The Principle of Loyalty in EU law, Oxford 2014.

Klip A., European Criminal Law. An Integrative Approach, 3rd ed., Cambridge 2016.

Šlosarčík I., Europeizace ústavniho postavení prezidenta České republiky (Europeanisation of the Constitutional Role of the President of the Czech Republic), "Jurisprudence", no. 2/2016, pp. 18-29.

Šlosarčík I., Constitutional Development in the Czech Republic in 2013-2017: Direct Presidential Elections and Their Constitutional Consequences, "European Public Law", no. 1/2018, pp. 43-53.

Ústava České republiky. Komentár (Constitution of the Czech Republic. Commentary), eds. L. Balýlová, J. Filip, P. Molek, Praha 2010. 